\title{
Phosphorus metabolism in planktonic communities of the eastern tropical Pacific Ocean
}

\author{
Yu. I. Sorokin \\ South Department of Oceanology Institute, Academy of Sciences of the USSR, Gelendzhik-7, Krasnodar, USSR
}

\begin{abstract}
Using $\mathrm{P}^{32}$, parameters of phosphorus metabolism were investigated in pelagic ecosystems of the Eastern Tropical Pacific Ocean. Rates of $\mathrm{PO}_{4}-\mathrm{P}$ consumption by microplankton in the surface water layer varied from 0.04 to 0.2 and 10 to $20 \mu \mathrm{g} \mathrm{P}^{-1} \mathrm{~d}^{-1}$ in oligotrophic and eutrophic waters respectively. In mesotrophic waters they were intermedial $\left(0.9\right.$ to $\left.2 \mu \mathrm{g} \mathrm{Pl}^{-1} \mathrm{~d}^{-1}\right)$. Turnover times varied from 40 to $100 \mathrm{~d}$ and 1 to $2 \mathrm{~d}$ in oligotrophic versus eutrophic pelagic communities. A good correlation between rates of $\mathrm{PO}_{4}-\mathrm{P}$ consumption and primary production, and the absence of such a correlation between ambient $\mathrm{PO}_{4}-\mathrm{P}$ contents and primary production, were documented. Of the total $\mathrm{PO}_{4}-\mathrm{P}$ consumed by microplankton in the surface water, 30 to $40 \%$ was utilized by bacterioplankton. This contribution of bacterioplankton to $\mathrm{PO}_{4}-\mathrm{P}$ consumption increased within the water column up to 70 to $90 \%$ at depths of 100 to $150 \mathrm{~m}$. The ratios: $\left[\mathrm{PO}_{4}-\mathrm{P}\right.$ consumed by phytoplankton to primary production] and $\left[\mathrm{PO}_{4}-\mathrm{P}\right.$ consumed by bacteria to microbial heterotrophic production] approximated the phosphorus contents in the biomass of algae and bacteria, respectively. The $\mathrm{PO}_{4}-\mathrm{P}$ consumption rate by phytoplankton in the dark was 1.5 to 2 times lower, and that by bacterioplankton 1.2 to 1.5 times higher, than in the light (at ambient illumination). Thus total $\mathrm{PO}_{4}-\mathrm{P}$ consumption in the dark was somewhat similar to that in the light. Using data on the rate of heterotrophic activity, the rates of $\mathrm{PO}_{4}$-P regeneration were calculated. The ratios of ['regenerated' primary production to total primary production] were determined. In oligotrophic waters these ratios were on average ca 0.7 to 1 . In mesotrophic waters they were 0.4 to 0.6 and in eutrophic waters 0.1 to 0.2 . From these data the velocity of water-mass ascending in the investigated areas of divergence and coastal upwellings was deduced. It varied from $3 \times 10^{-3}$ to $0.7 \times$ $10^{-4} \mathrm{~cm} \mathrm{~s}^{-1}$.
\end{abstract}

\section{INTRODUCTION}

At low ambient concentrations of the limiting nutrients nitrogen and phosphorus in the upper mixed layer of the stratified euphotic zone of the ocean, the rate of phytoplankton growth and the total level of productivity is controlled by their flow rates rather than by the actual quantity of their inorganic compounds in sea water (Pommeroy 1960, Menzel \& Ryther 1961a, Dugdale \& Goering 1967). Therefore, the level of primary production usually correlates poorly with ambient nutrient contents in surface waters (Hooper 1973, Thomas 1979, Eppley 1981). In fact, inorganic phosphorus contents at the level 0.2 to $0.5 \mu \mathrm{g}$-at $\mathrm{P}^{-1}$ (or even less) in surface layers are usual in areas of extensive phytoplankton blooms (in upwelling areas) and in oligotrophic waters where the rates of primary production can be 2 to 3 orders of magnitude lower. Thus attempts by hydrochemists to find correlations between these 2 values seem to be rather useless. The observed ambient nitrogen concentration in the upper mixed layer represents a dynamic equilibrium between inputs due to vertical mixing, biological regeneration, $\mathrm{N}_{2}$ fixation and nitrogen consumption. Therefore, instant nutrient concentration does not refer to the actual rate of primary production (Rigler 1956). Only estimation of the nutrient flow rates can provide real insights into the relations between nutrients and primary production. The most reliable method for measuring nutrient flow rates in the pelagic ecosystems is the use of isotopic labels i.e., $\mathrm{P}^{33}$ or $\mathrm{P}^{32}$ for phosphorus and $\mathrm{N}^{15}$ for nitrogen (Rigler 1956, Watt \& Hayes 1963, Johannes 1964, Dugdale \& Goering 1967. Sorokin \& Wyshkvartzev 1974, Faust \& Corell 1977. Eppley \& Peterson 1979). However, interpretation of estimations of $\mathrm{PO}_{4}-\mathrm{P}$ consumption rates by the natural planktonic assemblages thus obtained is complicated by the fact that the phytoplankton appears not to be its only consumer. A significant part is also consumed by bacterioplankton (Harris 1957, Watt \& Hayes 1963, 
Johannes 1964, Barsdate et al. 1974, Fedorov \& Sorokin 1977). Planktonic bacteria basically use the dissolved organic matter (DOM) which is most depleted in nutrients ( $\mathrm{N}$ and $\mathrm{P}$ ). For example, the content of phosphorus relative to carbon in the DOM of surface oceanic waters is ca $0.3 \%$ as compared with $6 \%$ in the microbial biomass. Also the $\mathrm{C} / \mathrm{N}$ ratio in DOM approximates 12 to 15 , being only 5 to 7 in the phytoplankton biomass (Romankevich 1979b). Therefore when using DOM as a nutrient source, planktonic bacteria must compensate for this deficiency of $\mathrm{P}$ and $\mathrm{N}$ by an additional consumption of inorganic nutrients in order to carry on biosynthesis from sea water (Sorokin 1978). Tentative estimation showed that bacterioplankton in tropical oceanic waters utilize up to $50 \%$ of the total $\mathrm{PO}_{4}-\mathrm{P}$ consumed by the microplankton. Obviously, in order to evaluate the rates of nutrient consumption by phytoplankton, it is necessary to estimate not only the total consumption by microplankton but also the part actually consumed by the phytoplankton itself. This problem can be solved more easily for $\mathrm{PO}_{4}$ - $\mathrm{P}$ consumption because of the availability of a very sensitive radio isotopic trace method. For inorganic-N consumption this problem appears to be more complicated, as the sensitivity of the $\mathrm{N}^{15}$ method is rather low, and there still exists no corresponding quantitative data.

During the 34th cruise of RV 'Academic Kurchatov' (Institute of Oceanology, Academy of Science of the USSR) we studied $\mathrm{PO}_{4}$-P consumption by microplankton in the areas of Equatorial divergence and of the Peruvian upwelling region. Rates of $\mathrm{PO}_{4}-\mathrm{P}$ consumption by phytoplankton and by planktonic bacteria were measured separately with the use of radiophosphorus label. Ratios between phosphorus consumption and production of organic matter by phytoplankton and bacteria were determined; and the ratios 'regenerated' production to total production in the phytoplankton were calculated.

\section{METHODS}

The rate of $\mathrm{PO}_{4}-\mathrm{P}$ consumption by microplankton was estimated using $\mathrm{P}^{32}$ (Sorokin \& Wyshkwartzev 1974, Fedorov \& Sorokin 1977). The 'working' solution of $\mathrm{P}^{32} \mathrm{O}_{4}$ was prepared by dilution of the initial stock with $4 \% \mathrm{NaCl}$ acid solution $\left(0.2 \mathrm{ml} \mathrm{HCl} 100 \mathrm{ml}^{-1}\right)$. The final 'working' solution contained $7 \mu \mathrm{gO}_{4}$-P $100 \mathrm{ml}^{-1}$ as a carrier. Its actual radioactivity measured under the G-M radiometer approximated $4 \times 10^{5} \mathrm{cpm} \mathrm{ml}^{-1}$. The solution was filtered through a membrane filter $(0.2 \mu \mathrm{m}$ pore size) and sterilized in sealed ampoules. During the bottle experiments 0.2 to $0.5 \mathrm{ml}$ portions of this solution were added per 0.25 to $0.5 \mathrm{l}$ of the subsample of $3 \mathrm{l}$ of water, taken at midday. From this volume
3 light bottles were filled: 2 experimental and 1 control. The control subsample was filtered, immediately after the addition of isotopic solution, through the membrane filter to estimate $\mathrm{PO}_{4}-\mathrm{P}$ consumption (which was not related to the process of biosynthesis). Control counts were less than $5 \%$ of experimental ones. The experimental bottles were incubated under simulated in situ condition in an aquarium during daylight. The rest of the 31 subsample was used to estimate $\mathrm{PO}_{4}-\mathrm{P}$ consumption at night. The bottles were incubated in the dark, from 1800 to $2000 \mathrm{~h}$, to measure the night uptake. Following exposure, the bottle subsamples were refiltered through the $0.2 \mu \mathrm{m}$ membrane filters They were then rinsed first with 3 subsequent portions of $0.2 \%$ solution of $\mathrm{H}_{3} \mathrm{PO}_{4}$ in sea water and then with a portion of neutral sea water. The radioactivity of $\mathrm{P}^{32}$ consumed by microplankton $\left(\mathrm{r}_{\mathrm{e}}\right)$ was measured on these filters employing a G-M radiometer. The amount of $\mathrm{PO}_{4}-\mathrm{P}$ consumed during the experiment ( $\mathrm{A}$ ) was calculated as

$$
A=\left(\frac{r_{e}-r_{c}}{R_{+}}\right) \cdot K \mu g P^{-1}
$$

where $r_{c}=$ radioactivity of the filter from the control bottle; $\mathrm{K}=\mathrm{PO}_{4}-\mathrm{P}$ content in the subsample $\left(\mu \mathrm{g} \mathrm{P} \mathrm{l}^{-1}\right)$; $\mathrm{R}_{+}=$radioactivity of a portion of the working solution of labelled phosphate. Possible errors of this procedure varied within $\pm 6 \%$. K was estimated by $\mathrm{Yu}$. A. Nalbandov (unpubl.) using 'Technicon' apparatus. $\mathrm{PO}_{4}-\mathrm{P}$ consumed per day $\left(A_{s}\right)$ represents the sum of double the amount of consumption in light bottles per $6 \mathrm{~h}$ exposure plus the consumption in dark bottles per $12 \mathrm{~h}$. Estimations of $\mathrm{A}$ in the water column down to $75 \mathrm{~m}$ were accomplished by exposure of bottles in the sea. Samples taken below this depth were exposed in the dark at in situ temperature.

To measure the $\mathrm{PO}_{4}-\mathrm{P}$ consumption separately for phytoplankton and bacteria, bottle subsamples were divided after exposure into 2 parts. One part was gently filtered by Nuclepore filters of $3 \mu \mathrm{m}$ pore size (without use of vacuum); on these filters radioactivity of the $\mathrm{PO}_{4}-\mathrm{P}$ consumed by phytoplankton was estimated. The other part was filtered on membrane filters of $0.2 \mu \mathrm{m}$ pore size to estimate the radiaactivity of $\mathrm{PO}_{4}$ $P$ consumed by the total microplankton $\left(r_{s}\right)$. Experiments demonstrated that a significant part of the phytoplankton (up to $40 \%$ ) passed through the $3 \mu \mathrm{m}$ filters. The actual amount of this loss was estimated separately in each of the experiments to calculate the necessary correction coefficient, assuming that $\mathrm{C}: \mathrm{P}$ uptake ratios were constant in both size fractions. To measure this loss the phytoplankton in the parallel subsample was labelled with $\mathrm{C}^{14}$ via photosynthesis by exposure during half of the daytime light in the presence of $\mathrm{C}^{14}$ bicarbonate. After the separation proce- 
dure described above and the counting of radioactivity of corresponding filters with the aid of liquid scintillation, the amount of the phytoplankton retained by the Nucleopore filters was calculated.

Primary phytoplankton production and production of bacterioplankton were measured with the aid of radiocarbon methods. For details consult Sorokin 1971 and Sorokin \& Kadota 1972. The tentative values of the rates of inorganic phosphorus regeneration in the upper water layers were calculated using data on decomposition rates by heterotrophic microplankton and mesozooplankton of organic matter in which the ratio $\mathrm{P}: \mathrm{C}$ (by mass) was around $1.4 \%$ (calculated by using values for phosphorus content in dissolved, particulated and living organic matter according to Ivanenkov 1979). Microbial respiration (M) was calculated as

$$
\mathrm{M}=\mathrm{P}\left(\frac{1-\mathrm{K}_{2}}{\mathrm{~K}_{2}}\right)
$$

where $\mathrm{P}=$ microbial production; $\mathrm{K}_{2}=$ bacterial efficiency coefficient for utilizing assimilated food for growth. Total decomposition rates were calculated as the sum of microbial respiration plus respiration of micro- and mesozooplankton. The latter was calculated using data on the biomasses of the main groups concerned and of their specific respiration rates in tropical waters (estimated during the cruise by E. A. Shushkina employing the methodology described in Shushkina 1977).

\section{RESULTS}

The positions of stations are shown in Fig. 1. Main rates of total $\mathrm{PO}_{4}-\mathrm{P}$ consumption by microplankton $\left(\mathrm{A}_{5}\right)$ in the surface layer are given in Table 1 together with data on primary production and ambient $\mathrm{PO}_{4}-\mathrm{P}$ contents in water. $A_{s}$ values varied over a wide range in different areas: from 0.04 to $12 \mu \mathrm{g} \mathrm{P} ~^{-1} \mathrm{~d}^{-1}$. Primary production varied also by 2 orders of magnitude from 0.7 to $280 \mathrm{mg} \mathrm{C} \mathrm{m}{ }^{-3} \mathrm{~d}^{-1}$. However ambient $\mathrm{PO}_{4}-\mathrm{P}$ contents in the upper mixed layer varied from 9 to $28 \mu \mathrm{g} \mathrm{P}^{-1}$, i.e. only 3 -fold. Moreover, in the areas of most extensive flourishing of phytoplankton (St. 3579 and 3580) it was 2 times less than in the oligotrophic waters at St. 3591 to 3593. Thus, between these 2 parameters (ambient $\mathrm{PO}_{4}-\mathrm{P}$ content and primary production) no positive correlation existed. There was, however, a high positive correlation between rates of $\mathrm{PO}_{4}-\mathrm{P}$ consumption $\left(\mathrm{A}_{5}\right)$ and primary production $(\mathrm{P})$ (Fig. 2). C: P uptake ratio was 23.2 .

In the oligotrophic waters of the North Trade Wind Current (St. $3536: 16^{\circ} \mathrm{N}, 148^{\circ} \mathrm{W}$ ) both $\mathrm{P}_{\mathrm{p}}$ and $\mathrm{A}_{\mathrm{s}}$ values were very low, i.e. more than 1 order of magnitude less

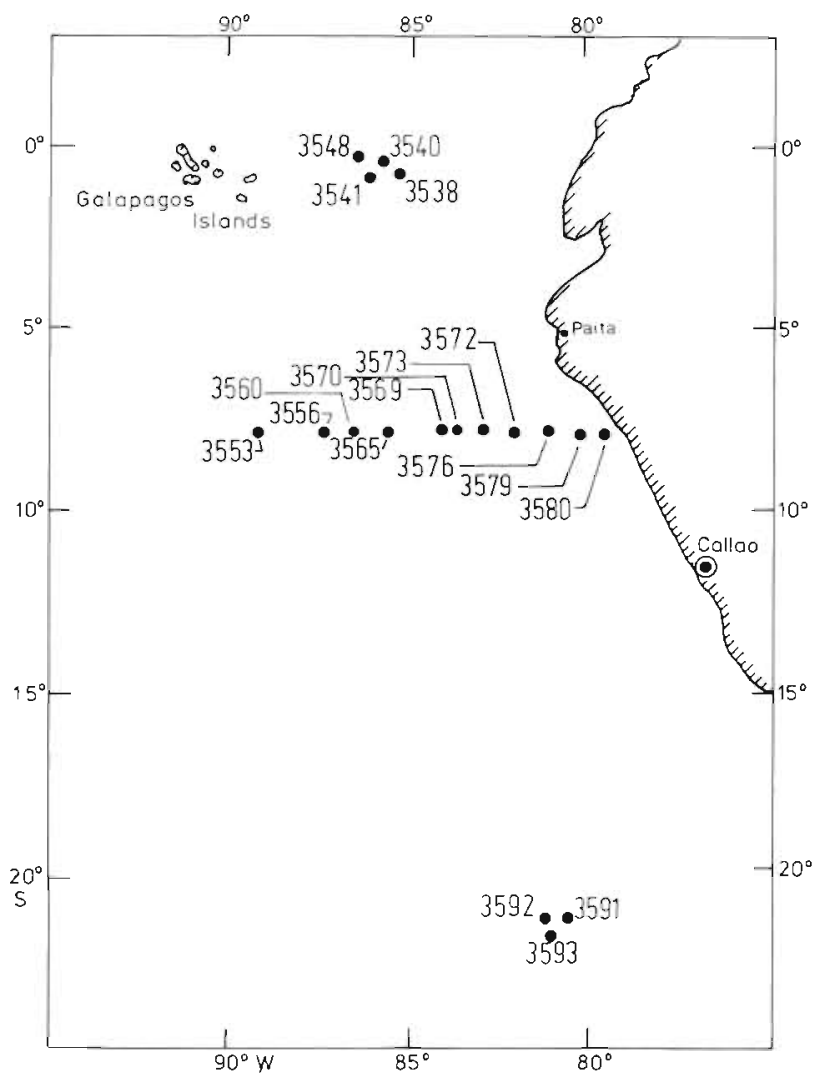

Fig. 1. Positions of stations. St. 3536 was situated at $16^{\circ} \mathrm{N}$ $148^{\circ} \mathrm{W}$

than in the mesotrophic waters. However, $\mathrm{PO}_{4}-\mathrm{P}$ concentration was only 2 times less than in eutrophic waters where the primary production was 2 to 3 orders higher (Table 1).

The turnover time of $\mathrm{PO}_{4}-\mathrm{P}(\mathrm{T}$ : Table 1) was shorter in the eutrophic waters of the coastal upwelling, where

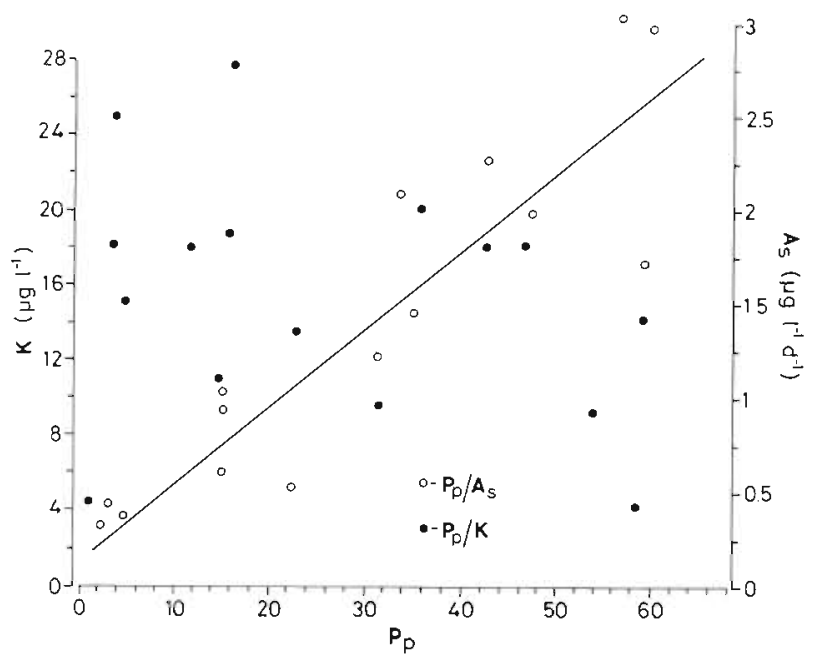

Fig. 2. Correlations between primary production $\left(P_{p} \mu g\right.$ $\mathrm{Cl}^{-1} \mathrm{~d}^{-1}$ ), total $\mathrm{PO}_{4}-\mathrm{P}$ uptake $\left(\mathrm{A}_{\mathrm{s}}\right)$ and ambient $\mathrm{PO}_{4}-\mathrm{P}$ concentrations $(K)$ in surface water: $P_{p} / A_{s}$ and $P_{p} / K$ 
Table 1 Rates of $\mathrm{PO}_{4}$-P consumption by microplankton in the upper water layer

\begin{tabular}{|c|c|c|c|c|c|c|c|c|c|}
\hline Region & Slation & $\begin{array}{l}\text { Primary pro- } \\
\text { duction of } \\
\text { phytoplankton } \\
\text { (mg }\left(\mathrm{m}^{-1} \mathrm{~d}^{-1}\right)\end{array}$ & $\begin{array}{l}\mathrm{PO}_{4}-\mathrm{P} \text { in } \\
\text { wates } \\
\left\{\mu \mathrm{g} \mathrm{l}^{-1}\right\}\end{array}$ & $\begin{array}{l}\text { Rate of } \mathrm{PO}_{4} \cdot \mathrm{P} \\
\text { consumption } \\
\left(\mu g \mathrm{Pl}^{-1} \mathrm{~d}^{-1}\right) \\
\left(\mathrm{A}_{3}\right)\end{array}$ & $\begin{array}{l}\text { Tumover } \\
\text { time of } \\
\mathrm{PO}_{4}-\mathrm{P}(\mathrm{d})\end{array}$ & $\begin{array}{l}\text { Caibulations } \\
\text { Rate of de- } \\
\text { composition } \\
\text { of organic } \\
\text { matter } \\
\left(\mathrm{mg} \mathrm{C} \mathrm{m}^{-1} \mathrm{~d}^{-1}\right)\end{array}$ & $\begin{array}{l}\text { of rates of } \mathrm{PO}_{4}-\mathrm{P} \\
\text { Rate of } \mathrm{PO}_{4}-\mathrm{P} \\
\text { regeneration } \\
\quad\left(\mathrm{A}_{r}\right)\end{array}$ & $\begin{array}{l}\text { regeneration } \\
\text { Excess or de- } \\
\text { ficit of regen- } \\
\text { erated PO } \mathrm{OO}_{4}-\mathrm{P} \\
\left(\mu \mathrm{gl}^{-1} \mathrm{~d}^{-1}\right) \\
\left(\mathrm{A}_{5}-\mathrm{A}_{8}\right)\end{array}$ & $\begin{array}{l}\text { Rate of up- } \\
\text { weiling } \\
\text { nesessany to } \\
\text { compensate } \\
\text { for } \mathrm{PO}_{4}-\mathrm{P} \text { de } \\
\text { ficit }\left(\mathrm{cm} \mathrm{s}^{-1}\right)\end{array}$ \\
\hline $\begin{array}{l}\text { Oligotrophic waters } \\
\text { of the Trade Wind } \\
\text { Current }\end{array}$ & 3536 & 0.7 & 4 & 0.04 & 100 & 16.0 & 0.22 & +0.18 & - \\
\hline $\begin{array}{l}\text { Cabo Nazca } \\
\text { ridge area }\end{array}$ & $\begin{array}{l}3591 \\
3592 \\
3593\end{array}$ & $\begin{array}{l}4.1 \\
3.0 \\
2.8\end{array}$ & $\begin{array}{l}15 \\
18 \\
25\end{array}$ & $\begin{array}{l}0.36 \\
0.41 \\
0.31\end{array}$ & $\begin{array}{l}42 \\
44 \\
80\end{array}$ & $\begin{array}{l}17.7 \\
25.2 \\
26.0\end{array}$ & $\begin{array}{l}0.25 \\
0.35 \\
0.36\end{array}$ & $\begin{array}{l}-0.09 \\
-0.06 \\
+0.04\end{array}$ & $\begin{array}{c}1.2 \times 10^{-4} \\
0.9 \times 10^{-4} \\
-\end{array}$ \\
\hline $\begin{array}{l}\text { Divergence to the } \\
\text { east of Galapagos } \\
\text { Islands }\end{array}$ & $\begin{array}{l}3538 \\
3540 \\
3541 \\
3548\end{array}$ & $\begin{array}{l}30.6 \\
15.8 \\
11.5 \\
31.5\end{array}$ & $\begin{array}{l}10 \\
19 \\
18 \\
17\end{array}$ & $\begin{array}{l}1.26 \\
0.93 \\
0.66 \\
2.14\end{array}$ & $\begin{array}{r}8 \\
20 \\
35 \\
8\end{array}$ & $\begin{array}{l}15.7 \\
25.6 \\
39.2 \\
30.6\end{array}$ & $\begin{array}{l}0.21 \\
0.36 \\
0.54 \\
0.43\end{array}$ & $\begin{array}{l}-1.05 \\
-0.57 \\
-0.12 \\
-1.71\end{array}$ & $\begin{array}{l}0.7 \times 10^{-4} \\
5.5 \times 10^{-4} \\
0.8 \times 10^{-4} \\
1.2 \times 10^{-3}\end{array}$ \\
\hline $\begin{array}{l}\text { Oceanic side of cross } \\
\text { section along } 8^{\circ} \mathrm{S} \text { to } \\
\text { the peruvian coast }\end{array}$ & $\begin{array}{l}3553 \\
3556 \\
3560 \\
3565 \\
3569 \\
3570\end{array}$ & $\begin{array}{l}14.9 \\
22.7 \\
15.4 \\
47.9 \\
35.4 \\
42.3\end{array}$ & $\begin{array}{l}28 \\
14 \\
11 \\
18 \\
21 \\
18\end{array}$ & $\begin{array}{l}0.61 \\
0.53 \\
0.94 \\
2.09 \\
1.50 \\
2.34\end{array}$ & $\begin{array}{r}45 \\
26 \\
12 \\
9 \\
14 \\
8\end{array}$ & $\begin{array}{r}7.1 \\
17.5 \\
28.9 \\
32.3 \\
38.1 \\
77.0\end{array}$ & $\begin{array}{l}0.10 \\
0.25 \\
0.40 \\
0.45 \\
0.53 \\
1.08\end{array}$ & $\begin{array}{l}-0.51 \\
-0.28 \\
-0.54 \\
-1.64 \\
-1.47 \\
-1.26\end{array}$ & $\begin{array}{l}4.0 \times 10^{-4} \\
9.3 \times 10^{-4} \\
5.3 \times 10^{-4} \\
7.6 \times 10^{-4} \\
7.3 \times 10^{-4} \\
9.1 \times 10^{-4}\end{array}$ \\
\hline $\begin{array}{l}\text { Area of divergence } \\
\text { along same section }\end{array}$ & $\begin{array}{l}3572 \\
3573 \\
3576\end{array}$ & $\begin{array}{l}54.1 \\
58.0 \\
58.0\end{array}$ & $\begin{array}{r}10 \\
5 \\
15\end{array}$ & $\begin{array}{l}3.15 \\
1.77 \\
3.03\end{array}$ & $\begin{array}{l}3 \\
3 \\
5\end{array}$ & $\begin{array}{l}60.5 \\
70.0 \\
87.4\end{array}$ & $\begin{array}{l}0.85 \\
0.98 \\
0.81\end{array}$ & $\begin{array}{l}-2.30 \\
-0.79 \\
-2.22\end{array}$ & $\begin{array}{l}1.6 \times 10^{-3} \\
5.8 \times 10^{-4} \\
1.7 \times 10^{-3}\end{array}$ \\
\hline $\begin{array}{l}\text { Area of coastal } \\
\text { upwelling }\end{array}$ & $\begin{array}{l}3579 \\
3580 \\
3580 \mathrm{a}\end{array}$ & $\begin{array}{r}251.0 \\
281.0 \\
1490.0\end{array}$ & $\begin{array}{r}13 \\
9 \\
9\end{array}$ & $\begin{array}{r}8.74 \\
11.84 \\
6.21\end{array}$ & $\begin{array}{l}1.5 \\
0.8 \\
1.4\end{array}$ & $\begin{array}{r}51.7 \\
97.3 \\
224.4\end{array}$ & $\begin{array}{l}0.72 \\
1.36 \\
3.14\end{array}$ & $\begin{array}{r}-8.02 \\
-10.48 \\
-3.07\end{array}$ & $\begin{array}{c}3.1 \times 10^{-3} \\
3.1 \times 10^{-3} \\
-\end{array}$ \\
\hline
\end{tabular}

its ambient concentration was low $\left(0.3 \mu \mathrm{g}\right.$-at $\left.\mathrm{l}^{-1}\right)$. Approaching the limiting concentration $(0.2 \mu \mathrm{g}$-at $\mathrm{P}$ $1^{-1}$, Thomas \& Dodson 1968), the rate of $\mathrm{PO}_{4}-\mathrm{P}$ consumption was maximal. Turnover time in this area was only 1 to $2 \mathrm{~d}$. The longest turnover time of $\mathrm{PO}_{4}-\mathrm{P}(40 \mathrm{~d}$, based on linear $\mathrm{PO}_{4}$-P uptake over $6 \mathrm{~h}$ ) was observed in oligotrophic waters (St. 3536 \& 3591 to 3593). Such a long turnover time at St. 3591 to 93 was recorded when the $\mathrm{PO}_{4}-\mathrm{P}$ content in the upper mixed layer was high $\left(0.5\right.$ to $\left.0.8 \mu \mathrm{g} \mathrm{P}^{-1}\right)$, i.e. where it exceeded the limiting concentration by about 5 times.

The calculated rates of regeneration of inorganic phosphate $\left(A_{T}\right)$ in the upper water layer are listed in Table 1. The values of $A_{r}$ have been used to evaluate necessary rates of external input of $\mathrm{PO}_{4}-\mathrm{P}$ into the upper water layers at the expense of the vertical hydrodynamic transport which could compensate its consumption. They were estimated as the difference between $A_{s}$ and $A_{r}$. The values in Table 1 demonstrate that in the oligotrophic waters, a larger part, if not the total, of the $\mathrm{PO}_{4}-\mathrm{P}$ consumption can be covered by 'regenerative' phosphate. In mesotrophic waters of the
Equatorial Divergence and of the divergence at the section along $8^{\circ} \mathrm{S}$, regeneration processes provided only 20 to $50 \%$ of the inorganic phosphorus demand. The remaining 50 to $80 \%$ of this demand had to be compensated for by physical transport (turbulence and upwelling processes) from the water layer below the thermocline. In the area of coastal upwelling the contribution of physical transport was the highest, up to $90 \%$. Here, a high rate of this hydrodynamic nutrient transport supported intensive phytoplankton growth in the upper mixed water layer at an extremely low ambient $\mathrm{PO}_{4}-\mathrm{P}$ supply. The rates of $\mathrm{PO}_{4}-\mathrm{P}$ flow from the lower water layers (Table 1) facilitate an estimation of the rate of upwelling.

Measurements of $A_{s}$ in the water column are given in Fig. 3 and in Table 2. The rate of $\mathrm{PO}_{4}-\mathrm{P}$ consumption was maximal near the surface or in the layer of the main microplankton maximum, which in the tropical stratified waters is usually situated near the upper boundary of thermocline (Sorokin 1971, 1973). The highest rate was recorded at St. 3580 in the area of coastal upwelling at $10 \mathrm{~m}$ depth, the layer of this 
Fig. 3. Total phosphorus uptake $\left(A_{5}, \mu g P^{-1} d^{-1}\right)$ in vertical profile. $t^{\circ}$ : water temperature; numbers at $A_{5}$ curves: turnover time of $\mathrm{PO}_{4}-\mathrm{P}(\mathrm{d})$

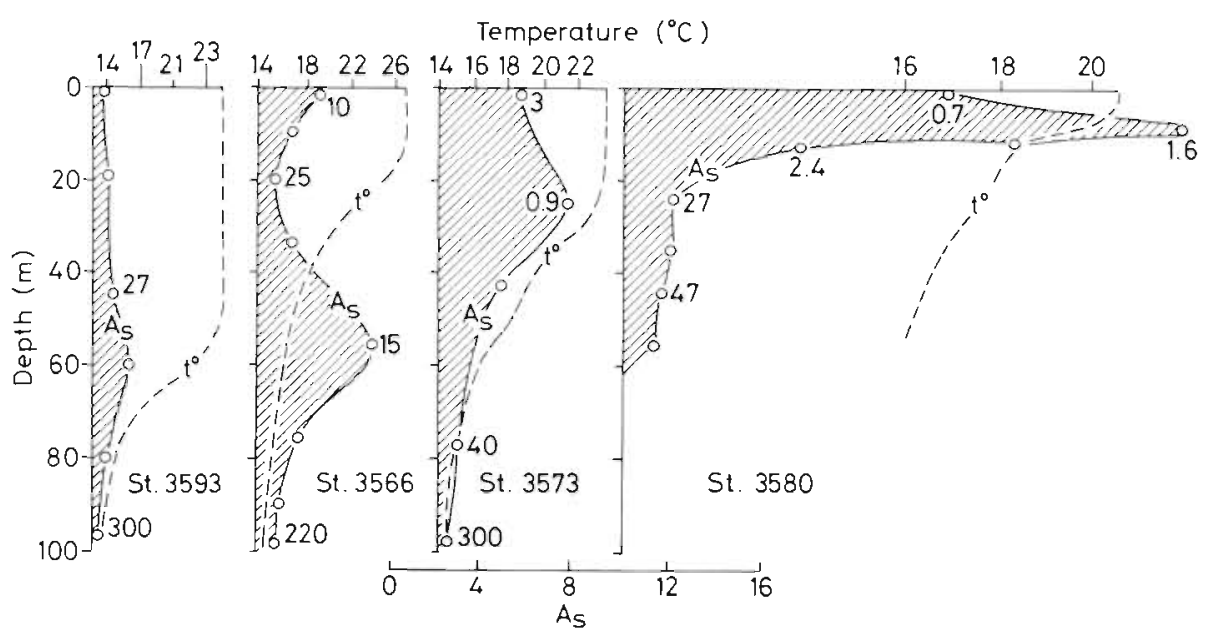

maximum $\left(21 \mu \mathrm{g} \mathrm{P}^{-1} \mathrm{~d}^{-1}\right)$. Turnover time of $\mathrm{PO}_{4}-\mathrm{P}$ in this layer was only 2 d even under conditions of extensive flow of inorganic phosphorus during upwelling of waters enriched with phosphate. The rate of $\mathrm{PO}_{4}-\mathrm{P}$ flow in the planktonic community was 2 orders of magnitude higher here than at St. 3593. Ambient $\mathrm{PO}_{4}^{-}$ $\mathrm{P}$ concentrations were equal in both sites.

Below the thermocline the rate of $\mathrm{PO}_{4}-\mathrm{P}$ consumption decreased, and its tumover time sharply increased up to 100 to $400 \mathrm{~d}$ (Table 2). Rates of $\mathrm{PO}_{4}$-P uptake, estimated separately for phytoplankton and bacterioplankton are given in Tables 3 and 4 . They document that a significant amount of inorganic phosphate in the upper layer was consumed by bacteria. At the different stations, bacterioplankton consumed 20 to $60 \%$ of the total $\mathrm{PO}_{4}-\mathrm{P}$ uptake. The remainder was consumed by phytoplankton. A lower percentage of microbial uptake was found in the young communities of the coastal upwelling area when the mass phytoplankton bloom occurred. In the more mature communities of mesotrophic waters, planktonic bacteria consumed 35 to $40 \%$ of the total uptake. The share of bacteria in the total $\mathrm{PO}_{4}-\mathrm{P}$ consumption increased considerably with increasing depth: at 60 to $100 \mathrm{~m}$ depth it was 70 to $80 \%$ of the total. Thus, within the euphotic zone bacteria accounts for about $50 \%$ of the total phosphorus uptake by microplankton.

Having obtained simultaneously the values for primary production of phytoplankton and for heterotrophic microbial production, from $\mathrm{PO}_{4}$-P consumption experiments, we calculated the ratios between $\mathrm{PO}_{4}-\mathrm{P}$ and these 2 components of microplankton which can consume inorganic phosphate. The ratio between phosphate consumption ( $\mu \mathrm{g} \mathrm{P}^{-1} \mathrm{~d}^{-1}$ ) and photosynthesis production $\left(\mu \mathrm{g} \mathrm{C} \mathrm{l}^{-1} \mathrm{~d}^{-1}\right)\left(\mathrm{A}_{\mathrm{s}} / \mathrm{P}_{\mathrm{p}}\right)$ of phytoplankton at most of the stations varied within relatively narrow limits: 1.4 to $4.4 \%$ (Table 3 ). These values are quite comparable with the average percent ratio $\mathrm{P}: \mathrm{C}$ in the phytoplankton biomass, which is close to 2 to $2.5 \%$ (Romankevich 1979a). According to experiments by Harrison \& Davies (1977), this ratio varied between 2.3 to $6 \%$.

At St. 3580a in the area of coastal upwelling near the Peruvian port Paita, the ratio $A_{s} / A_{J}$ was very low

Table 2. Rate of $\mathrm{PO}_{4}-\mathrm{P}$ consumption by microplankton $\left(\mathrm{A}_{\mathrm{s}}, \mu \mathrm{g} \mathrm{\textrm {l } ^ { - 1 }} \mathrm{d}^{-1}\right)$, and its turnover time ( $\mathrm{T}$, d) in the euphotic zone of equatorial and subtropical waters; $\mathrm{K}$ : $\mathrm{PO}_{4}$-P contents in water $\left(\mu \mathrm{gl}^{-1}\right) ; \mathrm{H}$ : depth $(\mathrm{m})$

\begin{tabular}{|c|c|c|c|c|c|c|c|c|c|c|c|c|c|c|c|}
\hline \multicolumn{4}{|c|}{ St. 3538} & \multicolumn{4}{|c|}{ St. 3540} & \multicolumn{4}{|c|}{ St. 3591} & \multicolumn{4}{|c|}{ St. 3579} \\
\hline$H(m)$ & $\mathrm{K}$ & $A_{p}$ & $\mathrm{~T}$ & $\mathrm{H}(\mathrm{m})$ & $\mathrm{K}$ & $A_{p}$ & $\mathrm{~T}$ & $\mathrm{H}(\mathrm{m})$ & $\mathrm{K}$ & $A_{p}$ & $\mathrm{~T}$ & $\mathrm{H}(\mathrm{m})$ & $\mathrm{K}$ & $A_{p}$ & $\mathrm{~T}$ \\
\hline 0 & 10 & 1.26 & 17 & 0 & 19 & 0.93 & 20 & 0 & 24 & 0.36 & 75 & 0 & 13 & 8.74 & 1.5 \\
\hline 7 & 8 & 0.98 & 8 & 8 & 19 & 0.50 & 38 & 15 & 23 & 0.31 & 74 & 11 & 19 & 9.8 & 1.9 \\
\hline 12 & 10 & 0.82 & 12 & 15 & 19 & 1.17 & 16 & 22 & 23 & 0.31 & 74 & 15 & 28 & 10.4 & 2.7 \\
\hline 20 & 6 & 0.44 & 14 & 30 & 31 & 0.27 & 114 & 30 & 16 & 0.25 & 64 & 25 & 56 & 13.0 & 4.3 \\
\hline 30 & 19 & 1.45 & 13 & 40 & 46 & 0.19 & 240 & 40 & 15 & 0.64 & 23 & 36 & 69 & 6.4 & 11 \\
\hline 45 & 32 & 2.20 & 15 & 55 & 47 & 0.17 & 280 & 70 & 14 & 1.78 & 8 & 70 & 58 & 0.81 & 70 \\
\hline 60 & 31 & 0.91 & 34 & 80 & 45 & 0.23 & 195 & 100 & 18 & 0.12 & 150 & 96 & 66 & 0.24 & 270 \\
\hline 90 & 37 & 0.77 & 48 & 100 & 48 & 0.11 & 440 & 125 & 29 & 0.10 & 290 & & & & \\
\hline 100 & 47 & 0.54 & 87 & 150 & 46 & 0.12 & 380 & 200 & 73 & 0.06 & 1200 & & & & \\
\hline 120 & 43 & 0.39 & 110 & 200 & 52 & 0.11 & 470 & & & & & & & & \\
\hline 150 & 40 & 0.22 & 180 & & & & & & & & & & & & \\
\hline
\end{tabular}


Table 3. Rate of $\mathrm{PO}_{4}$-P consumption by phytoplankton $\left(A_{p}\right)$ and bakterioplankton $\left(A_{b}\right)$ in the upper water layer; $A_{s}$ : total PO $-P$ consumption $\left(\mu \mathrm{g} \mathrm{l}^{-1} \mathrm{~d}^{-1}\right)$; $\mathrm{P}_{\mathrm{p}}$ : primary production of phytoplankton $\left(\mu \mathrm{g} \mathrm{Cl^{-1 }} \mathrm{d}^{-1}\right)$; $\mathrm{P}_{\mathrm{b}}$ : production of bacterioplankton $\left(\mu \mathrm{g} \mathrm{Cl}^{-1} \mathrm{~d}^{-1}\right.$.)

\begin{tabular}{|c|c|c|c|c|c|c|c|c|c|}
\hline Region & Station & $P_{b}$ & $A_{p}$ & $A_{b}$ & $\begin{array}{c}A_{b} / A_{s} \\
(\%)\end{array}$ & $\begin{array}{l}A_{p} / P_{p} \\
(\%)\end{array}$ & $\begin{array}{c}\mathrm{Ab}_{\mathrm{b}} / \mathrm{P}_{\mathrm{b}} \\
(\%)\end{array}$ & $\begin{array}{l}\text { Ratio of } \mathrm{PC} \\
\text { tion at light } \\
\text { by phyto- } \\
\text { plankton }\end{array}$ & $\begin{array}{l}\text {-P consump- } \\
\text { o that at dark } \\
\text { by bacte- } \\
\text { rioplankton }\end{array}$ \\
\hline $\begin{array}{l}\text { Equatorial area to east of } \\
\text { Galapagos islands }\end{array}$ & $\begin{array}{l}3538 \\
3540 \\
3548\end{array}$ & $\begin{array}{r}3.0 \\
10.9 \\
9.0\end{array}$ & $\begin{array}{l}0.87 \\
0.45 \\
1.39\end{array}$ & $\begin{array}{l}0.39 \\
0.48 \\
0.75\end{array}$ & $\begin{array}{l}31 \\
52 \\
35\end{array}$ & $\begin{array}{l}2.8 \\
2.8 \\
4.4\end{array}$ & $\begin{array}{l}6.3 \\
4.4 \\
5.3\end{array}$ & $\begin{array}{l}0.40 \\
0.40 \\
0.81\end{array}$ & $\begin{array}{l}0.81 \\
1.24 \\
1.36\end{array}$ \\
\hline $\begin{array}{l}\text { Ocaeanic side of Peru- } \\
\text { vian cross section } \\
\text { along } 8^{\circ} \mathrm{S}\end{array}$ & $\begin{array}{l}3556 \\
3560 \\
3569 \\
3570\end{array}$ & $\begin{array}{r}3.8 \\
8.5 \\
11.2 \\
22.4\end{array}$ & $\begin{array}{l}0.32 \\
0.49 \\
0.88 \\
1.65\end{array}$ & $\begin{array}{l}0.25 \\
0.45 \\
0.62 \\
0.69\end{array}$ & $\begin{array}{l}40 \\
49 \\
41 \\
42\end{array}$ & $\begin{array}{l}1.4 \\
3.1 \\
2.5 \\
3.9\end{array}$ & $\begin{array}{l}5.5 \\
5.2 \\
5.6 \\
3.1\end{array}$ & $\begin{array}{l}0.56 \\
0.64 \\
0.54 \\
0.72\end{array}$ & $\begin{array}{l}1.68 \\
1.40 \\
1.50 \\
1.46\end{array}$ \\
\hline $\begin{array}{l}\text { Areas of divergence and } \\
\text { coastal upwelling at } \\
\text { same section }\end{array}$ & $\begin{array}{l}3572 \\
3576 \\
3579 \\
3580 \\
3580 \mathrm{a}\end{array}$ & $\begin{array}{l}17.8 \\
25.8 \\
15.2 \\
28.6 \\
66.0\end{array}$ & $\begin{array}{l}1.86 \\
1.68 \\
6.64 \\
9.47 \\
5.33\end{array}$ & $\begin{array}{l}1.29 \\
1.35 \\
2.10 \\
2.37 \\
0.88\end{array}$ & $\begin{array}{l}41 \\
44 \\
24 \\
20 \\
16\end{array}$ & $\begin{array}{l}3.4 \\
2.9 \\
2.6 \\
3.4 \\
0.4\end{array}$ & $\begin{array}{l}7.2 \\
5.2 \\
5.8 \\
8.2 \\
1.8\end{array}$ & $\begin{array}{l}0.58 \\
0.75 \\
0.58 \\
0.61 \\
0.43\end{array}$ & $\begin{array}{l}1.25 \\
1.18 \\
1.45 \\
1.06 \\
1.25\end{array}$ \\
\hline
\end{tabular}

Table 4. Total $\mathrm{PO}_{4}-\mathrm{P}$ consumption $\left(\mathrm{A}_{s}\right)$ on vertical profile at St. 3556 , and $\mathrm{PO}_{4}-\mathrm{P}$ consumption only by bacterioplankton $\left(\mathrm{A}_{\mathrm{b}}\right)$ all values expressed as $\mu \mathrm{g} \mathrm{Pl}^{-1} \mathrm{~d}^{-1} ; \mathrm{P}_{\mathrm{b}}$ : production of bacterioplankton ( $\mu \mathrm{g} \mathrm{C}^{-1} \mathrm{~d}^{-1}$ ); other designations: see Table 2

\begin{tabular}{|rcccccr|}
\hline $\mathrm{H}(\mathrm{m})$ & $\mathrm{K}$ & $\mathrm{A}_{\mathrm{s}}$ & $\mathrm{A}_{\mathrm{b}}$ & $\begin{array}{c}\mathrm{A}_{\mathrm{b}} / \mathrm{A}_{\mathrm{s}} \\
(\%)\end{array}$ & $\begin{array}{c}\mathrm{A}_{\mathrm{b}} / \mathrm{P}_{\mathrm{b}} \\
(\%)\end{array}$ & $\mathrm{T}(\mathrm{d})$ \\
\hline 0 & 14 & 0.53 & 0.13 & 40 & 3.4 & 29 \\
15 & 13 & 0.35 & 0.18 & 53 & 3.2 & 17 \\
27 & 12 & 0.15 & 0.08 & 54 & 2.2 & 34 \\
42 & 24 & 0.14 & 0.092 & 68 & 4.2 & 75 \\
75 & 43 & 0.06 & 0.042 & 72 & 4.4 & 270 \\
130 & 48 & 0.011 & 0.009 & 85 & 5.0 & 4360 \\
190 & 51 & 0.012 & 0.011 & 91 & 2.7 & 4250 \\
\hline
\end{tabular}

$(0.4 \%)$. While primary production was extremely high there (1480 $\left.\mathrm{mg} \mathrm{Cm}^{-3} \mathrm{~d}^{-1}\right) ; \mathrm{PO}_{4}-\mathrm{P}$ uptake was reduced 2 -fold as compared with that at St. 3580 where primary production was 5 times less than that at St. 3580a. The cause of these anomalies seems clear. At St. 3580a we found a bloom of the red tide algae Gymnodinium splendens. The total population of this large dinoflagellate migrates at night down below the thermocline (Sorokin 1979). An extremely low $\mathrm{P}: \mathrm{C}$ ratio recorded at this station proves that in water layers rich in nutrients they consume and store phosphorus in sufficient amounts for sustaining intensive photosynthesis during the day when they ascend to the surface. Consequently, they consume less $\mathrm{PO}_{4}-\mathrm{P}$ when sampled in the middle of the day.

The ratio between $\mathrm{PO}_{4}$ - $\mathrm{P}$ uptake and microbial production (P:C) was on average about 5 to $6 \%$, which was also within the range of the $\mathrm{P}: \mathrm{C}$ ratio in microbial biomass (6 to $8 \%$ ) (Rose 1968). A higher variability of this ratio at the different sites investigated (2.1 to 7.2) presumably reflects the fact that for bacteria $\mathrm{PO}_{4}-\mathrm{P}$ uptake is not the only source of phosphorus. They also utilize organic phosphorus (Rose 1968).

Estimations of $\mathrm{PO}_{4}-\mathrm{P}$ uptake, separately assessed for phytoplankton and bacterioplankton in light and dark bottles (Table 3), demonstrate that planktonic algae consumed 1.5 to 2 times less $\mathrm{PO}_{4}$ - $\mathrm{P}$ at night than during the day. The bacterioplankton, on the other hand, was less active in this respect in the light bottles during the daytime. Total $\mathrm{PO}_{4}$-P uptake was about equal during the day and at night at the majority of stations. Comparable data was presented by Faust \& Corell (1977).

\section{DISCUSSION}

In the oligotrophic waters at St. 3536 where primary production at the surface was less than $1 \mathrm{mg} \mathrm{C} \mathrm{m}^{-3} \mathrm{~d}^{-1}$, $\mathrm{PO}_{4}$-P uptake $\left(\mathrm{A}_{\mathrm{s}}\right)$ was $0.04 \mu \mathrm{g} \mathrm{l}^{-1} \mathrm{~d}^{-1}$. In accordance with Goering et al. (1970) and Eppley et al. (1977), uptake of inorganic nitrogen in waters of the same level of productivity was 7 to $25 \mu \mathrm{g} \mathrm{N} \mathrm{l}^{-1} \mathrm{~d}^{-1}$, based on $N^{15}$ data. Since the ratio N:P (by mass) in phytoplankton biomass is ca $6: 1, \mathrm{PO}_{4}-\mathrm{P}$ uptake in these waters should be ca 0.02 to $0.07 \mu \mathrm{P} \mathrm{l}^{-1} \mathrm{~d}^{-1}$, which is close to our direct measurements. In more productive coastal areas, Pomeroy (1960) measured an uptake of $\mathrm{PO}_{4}-\mathrm{P}$ in the upper water layers of 2 to $15 \mu \mathrm{g} \mathrm{l}^{-1} \mathrm{~d}^{-1}$. Compared to our data (Table 1), such a level is peculiar to mesotrophic to eutrophic oceanic waters. The turnover time of $\mathrm{PO}_{4}$ - $\mathrm{P}$ in planktonic communities of different marine and freshwater basins varies within a wide range: from 0.5 to $200 \mathrm{~h}$ (Rigler 1956, Hayes \& Phillips 1958, 
Pomeroy 1960). In freshwater a short turnover time could occur either at low ambient $\mathrm{PO}_{4}$-P concentrations or at high phytoplankton growth rates, or with both phenomena present. In accordance with our data, the short turnover time ( 1 to $2 \mathrm{~d}$ ) in marine communities prevailed mostly in the latter situation (St. 3580; Table 1). In a mature pelagic ecosystem of stratified tropical waters, the turnover time could be large (more than $40 \mathrm{~d}$ ) either at low or at relatively high phosphate contents (compare St. 3536 with St. 3591 to 3593; Table 1). In the first case, phytoplankton growth rate (and thus microbial growth and $\mathrm{PO}_{4}-\mathrm{P}$ uptake) was apparently limited by a low ambient $\mathrm{PO}_{4}$-P concentration in the mixed water layer. In the second case, microplankton growth seemed to have been limited by zooplankton grazing pressure (Eppley 1981).

In accordance with measurements by Sorokin \& Wyshkvarzev (1974), turnover time in the upper mixed Iayer of oligotrophic waters of the western part of the Pacific Ocean was fairly long (95 to $120 \mathrm{~d}$ ). Comparison of production values and total $\mathrm{PO}_{4}-\mathrm{P}$ uptake (Table 1) gives a good correlation between these parameters (correlation coefficient $\mathrm{r}=0.98$; Fig. 2). A correlation between primary production and ambient $\mathrm{PO}_{4}-\mathrm{P}$ contents was completely absent. At the limited nutrient contents and at the high turnover rates in the euphotic zone, this situation appeared to be quite obvious (Menzel \& Ryther 1961a). A direct dependence of primary production rate on the rate of nutrient input into the euphotic zone at appropriate surfaceillumination conditions was documented by Pomeroy (1960), Kramer (1972), Hooper (1973), Thomas (1979) and Eppley (1981). Although there was no correlation between ambient $\mathrm{PO}_{4}-\mathrm{P}$ concentration and primary production in water samples from the upper mixed layer, a good correlation existed between primary production and reverse depth values of the upper boundary of the $\mathrm{PO}_{4}-\mathrm{P}$ gradient zone $\left(\frac{100}{Z}\right)$, as can be seen in Fig. 4. The reason for such a correlation is obvious: the depth of the gradient zone in quasi-permanently stratified water basin depends on upwelling of deep waters to the surface. Its depth position controls the rate of $\mathrm{PO}_{4}-\mathrm{P}$ input into the euphotic zone, and thus the level of primary production (Eppley 1981).

The correlation between total $\mathrm{PO}_{4}-\mathrm{P}$ uptake and primary production is complex because a significant portion of $\mathrm{PO}_{4}-\mathrm{P}(30$ to $40 \%)$ is consumed by bacterioplankton. However, because the general level of heterotrophic microbial activity itself correlates with the level of primary production, a large microbial uptake of $\mathrm{PO}_{4}-\mathrm{P}$ actually does not interfere with the correlation between total $\mathrm{PO}_{4}-\mathrm{P}$ uptake and primary production. The correlation between $\mathrm{PO}_{4}-\mathrm{P}$ uptake by phytoplakton itself and primary production $\left(A_{p} / P_{p}\right)$ is

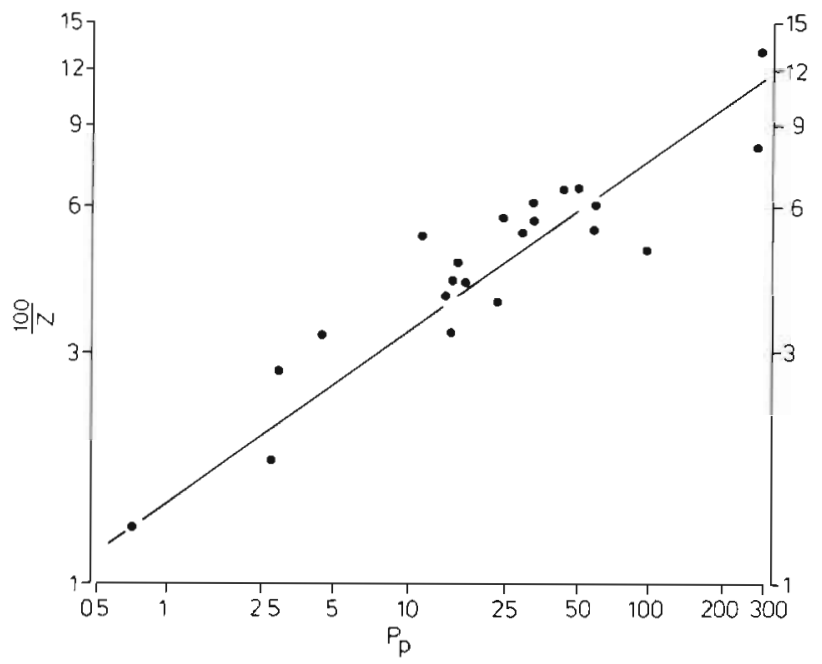

Fig. 4. Correlation between reverse depth of upper boundary of $\mathrm{PO}_{4}-\mathrm{P}$ gradient zone $\left(\frac{100}{\mathrm{Z}}\right)$ and primary production $\mathrm{P}_{\mathrm{p}}$ (mg C m${ }^{-3} \mathrm{~d}^{-1}$ ). Z: depth of zone $(\mathrm{m})$

even higher ( $r=0.99$ ), which is obvious. The average percent ratio $A_{p} / P_{p}(3.3 \%)$ is remarkably similar to the $\mathrm{P} / \mathrm{C}$ ratio in phytoplankton biomass (Table 3 ). This definitely supports the reliability of the $C^{14}$ primary production data, as well as the relative adequacy of $\mathrm{PO}_{4}-\mathrm{P}$ measurements of the phosphorus uptake. The data given in Table 3 and 4 indicate that, in the surface layer of tropical waters of different ranges of productivity, 30 to $40 \%$ of $\mathrm{PO}_{4}-\mathrm{P}$ was consumed by bacterioplankton. In lower water layers of the euphotic zone this percentage doubled. Thus the bacterioplankton appears to be an important competitor of phytoplankton for inorganic nutrients under conditions of nutrient limitation, which is typical for stratified waters, not only in the tropical but also in the temperate ocean regions (Sorokin 1977). Such competition involves not only phosphorus but to a lesser degree also nitrogen. The latter statement becomes obvious if we take into account the fact that the $C: N$ ratio in microbial biomass is 5 to 6 . This is about 2 -fold lower than in sea water DOM which is a main food source for planktonic bacteria (Romankevich $1979 \mathrm{~b}$ ). The probability of the consumption of part of the inorganic nitrogen by microheterotrophs, most probably by bacteria, was demonstrated with the aid of N label (Goering 1970. Eppley et al. 1977). The bacteria, as competitors of inorganic nutrients, appear to have a definite advantage compared with phytoplankton. Their cells have a larger relative surface, and they possess also a more intensive active enzyme transport (Allen 1969). Thus bacteria can consume the small molecules at lower ambient concentrations than the phytoplankton. Therefore, the role of bacteria as competitors must be expected to increase, especially in oceanic waters with 
depleted nutrients. While oceanic $\mathrm{PO}_{4}-\mathrm{P}$ levels are often below the sensitivity threshold of analytic methods (1 $\left.\mu \mathrm{g} \mathrm{P}^{-1}\right)$, the concentration limit for phytoplankton growth is several times higher $\left(5 \mu \mathrm{g} \mathrm{PO}_{4}-\mathrm{P}\right.$ $1^{-1}$ ). It seems most probable therefore, that the observed decrease in ambient concentrations of inorganic phosphorus below analytical zero is a consequence of its consumption by bacterioplankton. A relatively high metabolic activity in tropical oligotrophic waters with depleted nutrients has been documented (Sorokin 1971, 1973). In accordance with these observations, it was supposed that, in the upper layers of warm waters, microbial decomposition occurs of a significant part of the organic matter produced in the World Ocean, especially the decomposition of its stable fractions (for a discussion of this problem consult Sorokin 1978). If this is the case, the DOM of oceanic waters, subject to microbial decomposition in tropical surface waters being transferred from other regions of the ocean, becomes nutrient depleted, especially in terms of phosphorus. Therefore, the microbial populations of these waters when using this 'allochthonous' organic matter have to consume additional portions of inorganic nutrients.

When stressing the role of bacterioplankton as a consumer of $\mathrm{PO}_{4}-\mathrm{P}$ it is necessary to take into account also its role in the regeneration of inorganic nutrients from stable polymeric organo-phosphorus compounds, constantly present in surface oceanic waters in significant amounts ( 3 to $8 \mu \mathrm{P} \mathrm{I}^{-1}$ ); mostly phospholipids and nucleic acids. The mechanism of their regeneration appears to be as follows: organic phosphorus is consumed by planktonic bacteria, then the phosphorus of the microbial biomass is remineralised via the food chain after its consumption by grazers and, finally, is added to the $\mathrm{PO}_{4}-\mathrm{P}$ pool of sea water. This mechanism of mobilization of the stock of organic phosphorus in surface oceanic waters should be recognized as an important source of regenerative phosphorus in tropical oceanic waters.

Using the data on the rate of decomposition of organic matter in upper water layers, we have made an attempt to calculate the rate of $\mathrm{PO}_{4}$-P regeneration and to evaluate the role of this process of regeneration in the phosphorus turnover in different planktonic communities (Table 1). The rates of $\mathrm{PO}_{4}-\mathrm{P}$ regeneration thus obtained were used for computing the $\mathrm{PO}_{4}-\mathrm{P}$ input into the community required for maintaining the rate of phosphorus uptake actually observed here; and also the necessary rate of upwelling of nutrient-rich waters from the deeper layers required for providing this input. The rates of upwelling thus obtained (Table 1) appear to be $0.7 \times 10^{-4} \mathrm{~cm} \mathrm{~s}^{-1}$ in mesotrophic waters and $3 \times 10^{-3} \mathrm{~cm} \mathrm{~s}^{-1}$ in the eutrophic waters of coastal upwelling areas. These values, in general, coincide with those observed by physical methods of measurement of the vertical component of currents in corresponding areas (Polosin 1967, Yoshida 1967, Fedorov 1975).

Insights into the interactions of primary production and nutrient metabolism have been provided by studies (Dugdale \& Goering 1967, Eppley et al. 1977, Eppley 1981) separating the 'regenerative' and the 'new' portions of the total phytoplankton primary production, using $\mathrm{N}^{15}$ label. The ratio of 'regenerated' to total primary production $\left(\mathrm{P}_{\mathrm{r}} / \mathrm{P}_{\mathrm{p}}\right)$ was found to be a good ecological indicator of the state of a planktonic community - of its level of production, sources of nutrient supply, degree of zooplankton grazing, etc. Routine estimations of this important ratio, using the $\mathrm{N}^{15}$ method, have a relatively low sensitivity, especially in oligotrophic waters, where the rates of these processes are extremely low. The acetylen method, a part of the methodology for estimating total $\mathrm{N}^{15}$ uptake necessary for assessing the 'new' primary production, is indirect and hence also has a limited sensitivity.

Data on rates of total $\mathrm{PO}_{4}-\mathrm{P}$ consumption $\left(\mathrm{A}_{5}\right)$ and of $\mathrm{PO}_{4}-\mathrm{P}$ regeneration $\left(\mathrm{A}_{\mathrm{r}} ;\right.$ Table 2$)$ provided the possibility of computing the ratio of the 'regenerative' to total primary production $\left(\mathrm{P}_{\mathrm{r}} / \mathrm{P}_{\mathrm{p}}\right)$ (Table 2). The regenerative' production was calculated as $P_{r}=\frac{A_{r} \cdot P_{p}}{A_{s}}$, the 'new' primary production would be equal to the difference $P_{t}-P_{r}$, and the ratio 'regenerated' to total primary production $\left(\mathrm{P}_{\mathrm{r}} / \mathrm{P}_{\mathrm{p}}\right)$ would be equal to $\mathrm{A}_{\mathrm{r}} / \mathrm{A}_{\mathrm{s}}$. The part of total phosphorus uptake $\left(\mathrm{A}_{\mathrm{s}}\right)$ consumed by bacterioplankton is actually consumed from the total $\mathrm{PO}_{4}-\mathrm{P}$ pool. Therefore, microbial uptake does not influence the $A_{r} / A_{s}$ ratio nor, consequently, the ratio $P_{r} / P_{p}$.

Calculations of corresponding values are given in Fig. 5. They demonstrate a quite definite correlation between the ratio $\mathrm{P}_{\mathrm{r}} / \mathrm{P}_{\mathrm{p}}$ and the level of primary production within the limits reported by Eppley (1981). In oligotrophic waters this ratio was 0.6 ; in mesotrophic waters it ranged from 0.3 to 0.5 ; and in eutrophic waters it was as low as 0.1 to 0.2 . A deviation from such regularity was observed only in eutrophic water at St. 3580a $\left(P_{\mathrm{r}} / \mathrm{P}_{\mathrm{p}}=0.5\right)$. The cause of deviation appears to have been the above-mentioned 'red tide' caused by the dinoflagellate Gynodinium splendens, which contributed to an unaccounted for 'new' production at the expense of the phosphorus consumed at night below the thermocline during night-time migration. In oligotrophic waters, where the upper boundary of the thermocline sank to 60 to $80 \mathrm{~m}$ depth, a larger part of the primary production appears to have been of 'regenerative' origin, because the flow of nutrients from the lower water layers is slight (Eppley et al. 1973, Eppley \& Peterson 1979, Eppley 1981). Therefore, in these waters the $\mathrm{P}_{\mathrm{r}} / \mathrm{P}_{\mathrm{p}}$ ratio approached 1 . Corresponding 


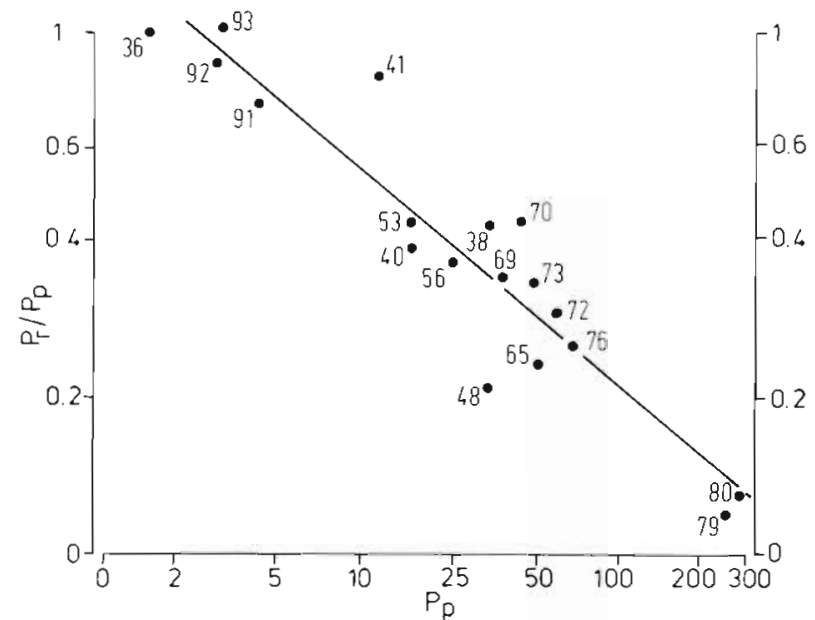

Fig. 5. Correlation between the ratio 'regenerative' primary production to total primary production $\left(\mathrm{P}_{\mathrm{r}} / \mathrm{P}_{\mathrm{p}}\right)$, and actual primary production values $\left(P_{p}\right.$ mg $\left.C \mathrm{~m}^{-3} \mathrm{~d}^{-1}\right)$. Numbers near points are abbreviated station numbers

ratios have been obtained in our experiments (St. 3591 to 93,3536 ; Fig. 5).

It is remarkable that, in accordance with the low level of primary production and the low position of the thermocline, waters at St. 3591 to 3593 can be referred to as oligotrophic. Nevertheless, the $\mathrm{PO}_{4}-\mathrm{P}$ content was still high $\left(0.6\right.$ to $0.8 \mu \mathrm{g}$-at $\left.\mathrm{P}^{-1}\right)$, i.e. it was about twice that in the surface waters of the coastal upwelling area. What could be the cause of this situation (which we had often observed before) especially in the Eastern Pacific Ocean, south of the South Equatorial Divergence? When discussing the apparent incomplete utilization of ambient nutrients in the upper mixed layer by phytoplankton, Thomas (1979) pointed out the following: (i) upwelling speed exceeds the rate of phytoplankton growth; (ii) phytoplankton growth is limited by insufficiently abundant nutrient, possibly a che-

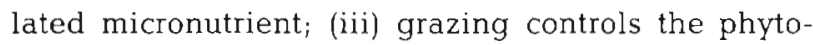
plankton population. In accordance with our observations the main cause (outside the 'blue pools' in coastal upwelling areas) should be the latter one, i.e. grazing control under conditions of steady-state in a mature pelagic ecosystem of tropical stratified waters. The permanent stratification stabilizes nutrient input into the euphotic zone, from the deeper layer, at a constant low level (Table 1, St. 3591 \& 3592). In this situation a predominant part of the primary production is grazed by zooplankton (Cushing 1958, Petipa \& Makarova 1969, Sorokin 1973). In accordance with Eppley (1981) the ratio $\mathrm{P}_{\mathrm{r}} / \mathrm{P}_{\mathrm{p}}$ appears to be a good indicator also of the degree to which grazing controls phytoplankton growth in pelagic plankton communities. Where this ratio is close to 1 , grazing completely controls the phytoplankton growth. It could be supposed that in this situation the community is balanced at a low level of biomass of either autotrophs or heterotrophs in correspondence with the low level of nutrient flow. Direct estimations (Shushkina unpubl.), during the cruise, of the degree of grazing of ambient phytoplankton biomass, by calculating the food rations of micro- and mesozooplankton based on methodology given by Shushkina et al. (1980), supports this conclusion. At St. 3536 and 3591 to 3593 , where $P_{r} / P_{p}$ is close to 1 , zooplankton grazed more than half the phytoplankton production per day (see Table 5). Under these condi-

Table 5. Ratio of regenerative to total primary production $\left(\mathrm{P}_{\mathrm{r}}\right)$ $P_{p}$ ), and grazing of phytoplankton by zooplankton per day ( $\%$ of ambient phytoplankton biomass) at several stations. Values of grazing from E. A. Shushkina (unpubl.)

\begin{tabular}{|lccc|}
\hline $\begin{array}{l}\text { Level of production; range } \\
\text { of primary production, } \mathrm{P}\end{array}$ & Station & $\mathrm{P}_{\mathrm{r}} / \mathrm{P}_{\mathrm{p}}$ & $\begin{array}{c}\text { Grazing } \\
\%\end{array}$ \\
\hline Oligotrophic; & 3536 & 1.0 & 72 \\
$\mathrm{P}<4 \mathrm{mg} \mathrm{C} \mathrm{m}{ }^{-3} \mathrm{~d}^{-1}$ & 3591 & 0.7 & 65 \\
Mesotrophic; & 3538 & 0.4 & 52 \\
$\mathrm{P}=15-58 \mathrm{mg} \mathrm{C} \mathrm{m}^{-3} \mathrm{~d}^{-1}$ & 3573 & 0.3 & 50 \\
& 3576 & 0.2 & 32 \\
Eutrophic; & 3579 & 0.1 & 29 \\
P>250 $\mathrm{mg} \mathrm{C} \mathrm{m}^{-3} \mathrm{~d}^{-1}$ & 3580 & 0.1 & 24 \\
\hline
\end{tabular}

tions, in the upper mixed layer, gradual accumulation of inorganic regenerative nutrients occurs. An instant utilization of this accumulating stock of nutrients by phytoplankton does not occur, probably because its population is scarce. This can be deduced from the long turnover time of $\mathrm{PO}_{4}-\mathrm{P}$ in such areas $(\sim 40 \mathrm{~d})$.

It seems most likely that the accumulating stock of regenerated nutrients can be utilized under these conditions only via periodical peaks of phytoplankton growth. Such peaks can occur when the phytoplankton abundance in the upper mixed layer increases up to a level which can support the necessary rates of multiplication of several mass species of algae sufficiently to counteract the pressure of grazing. Then their developing bursts are later sequenced by the enhanced activity of bacterioplankton. Bacterioplankton, together with the algae, consumes the stock of the previously accumulated nutrients below the analytical zero, and again the planktonic system becomes stabilized at low levels of biomass and nutrient flow. Thus, the functioning of such limited pelagic communities in tropical ocean areas inevitably has to proceed via peaks of activity not obviously seasonal. When the nitrogen in these communities is at the lower limits, 'blooms' are usually induced by nitrogen-fixing blue-green algae. In order to observe the precise regime of such succession it would be necessary to accomplish permanent observations in pelagic tropical ecosystems, which is 
still a very rare case. But the data at hand (Menzel \& Ryther 1960, 1961b) indicate the possibility of such bursts of phytoplankton growth in the ultraoligotrophic waters of the Sargasso Sea. In fact, it is not simple to document such supposed peaks because they are rather short, compared to the much longer periods of heterotrophic steady-state development.

Finally I would like to stress the importance of the ultranannoplankton fraction of autotrophs in the buildup of primary production (Malone 1971, McCarthy et al. 1974, Johnson \& Sieburth 1979). In our experiments, 20 to $50 \%$ of the primary production activity passes through the Nuclepore filter with a pore size of $3 \mu \mathrm{m}$ when filtered without vaccuum.

\section{LITERATURE CITED}

Allen, H. L. (1969). Chemoorganotrophic utilization of dissolved organic compounds by planktonic algae and bacteria in a pond. Int. Revue ges. Hydrobiol. 54: 1-33

Barsdate, R. J., Prentkti, R., Fenchel, T. (1974). Phosphorus cycle of model ecosystems: significance and effect of bacterial grazers. Oikos 25: 239-257

Cushing, D. H. (1958). The effect of grazing in reducing primary production. Rapp. P.-v. Réun. Cons, perm. int. Explor. Mer 144: 149-157

Dugdale, R. C., Goering, J. J. (1967). Uptake of new and regenerated forms of nitrogen in primary productivity. Limnol. Oceanogr. 12: 196-206

Eppley, R. W. (1981). Autotrophic production of particulate matter. In: A. Longhorst (ed.) Analysis of marine ecosystems. Academic Press, New York, p. 343-361

Eppley, R. W., Peterson, B. J. (1979). Particulate matter flux and planktonic new production in the deep ocean. Nature, Lond. 282: 677-680

Eppley, R. W., Renger, E. H., Venrick, E. L., Mullin, M. M. (1973). A study of planktonic dynamics and nutrient cycling in the central gyre of the North Pacific Ocean. Limnol Oceanogr. 18: 534-551

Eppley, R W., Sharp, J. H., Renger, E. H., Perry, M. J., Harrison, W. G. (1977). Nitrogen assimilation by phytoplankton and other microorganisms in the surface waters of the Central North Pacific Ocean. Mar. Biol. 39: 111-120

Faust, M. A., Corell, D. L. (1977). Autoradiographic study to detect metabolically active phytoplankton and bacteria in the Rhode River estuary. Mar. Biol. 41: 293-306

Federov, V K. (1975). Estimation of the vertical rate in equatorial upwelling. (Russ.). Trans. Inst. Oceanol. Acad. Sci. USSR, Moscow 102: 41-46

Fedorov, K. N., Sorokin, Yu. I. (1977). Consumption of inorganic phosphate by bacteria and phytoplankton in the Eastern Pacific. (Russ.). Polskie Arch. Hydrobiol. 24: 261-267

Goering, J. J., Wallen, D. D., Nauman, R. A. (1970). Nitrogen uptake by phytoplankton in the discontinuity layer of the Eastem Subtropical Pacific Ocean. Limnol. Oceanogr. 15 $789-796$

Harris, E. (1957). Radiophosphorus metabolism in zooplankton and microorganisms. Can. J. Zool. 35: 769-782

Harrison, W. G., Davies, J. M. (1977). Nitrogen cycling in marine planktonic food web. Mar. Biol. 43: 299-306

Hayes, J. R., Phillips, J. E. (1958). Radiophosphorus equilib- rium with mud, plants and bacteria under oxidized and reduced conditions. Limnol. Oceanogr. 3: 454-475

Hooper, F. F. (1973). Origin and fate of organic phosphorus compounds in aquatic systems. In: Griffith (ed.) Environmental phosphorus handbook. Wiley, New York, p. $179-202$

Ivanenkov, V. N. (1979). The general regularities in distribution of nutrients in the world ocean. (Russ.). In: Volkov, I. I. (ed.) Chemistry of ocean, Vol. I. Nauka, Moscow, p. $188-227$

Johannes, R. E. (1964). Release and uptake of dissolved organic phosphorus by representatives of a coastal marine ecosystem. Limnol. Oceanogr. 9: 224-234

Johnson, P. W., Sieburth, J. N. (1979). Chroococcoid cyanobacteria in the sea. Limnol. Oceanogr. $24 ; 928-935$

Kramer, J. R. (1972). Phosphorus: analysis of water, biomass sediment. In : Allen, H., Kramer, J. R. (ed.) Nutrients in natural waters. Wiley, New York, p. 51-100

Malone, T. C. (1971). The relative importance of nannoplank ters and net plankton in primary production in oceanic communities. Limnol. Oceanogr. 16: 633-639

McCarthy, J. J., Taylor, W. R., Loftus, M. E. (1974). The significance of nannoplankton in the Chesapeake Bay Estuary. Mar. Biol, 24: 7-14

Menzel, D. W., Ryther, J. H. (1960). The annual cycle of primary production in the Sargasso Sea, Bermuda. Deep Sea Res. 6: 351-367

Menzel, D. W., Ryther, J. H. (1961a). Nutrients limiting of the phytoplankton in the Sargasso Sea. Deep Sea Res. 7: 276-281

Menzel, D. W., Ryther, J. H. (1961b). Annual variations in primary production of the Sargasso Sea off Bermuda. Deep Sea Res. 7: 282-288

Petipa, T. S., Makarova, N. P. (1969). Dependence of phytoplankton production on rhythm and rate of elimination Mar. Biol. 3: 191-195

Polosin, A. S. (1967). On the zero surface in the equatorial zone of the Atlantic Ocean. (Russ.). Okeanologia (Moscow) 7: 89-97

Pomeroy, L. R. (1960). Residence time of dissolved $\mathrm{PO}_{4}$ in naural waters. Science 131: 1731-1732

Rigler, F. H. (1956). A tracer study of the phosphorus cycle in lake water. Ecology 37: 550-562

Romankevich, E. A. (1979a). Sources of organic matter and the biochemical composition of the producers and consumers. In: Volkov, I. I. (ed.) Chemistry of ocean, Vol. I. Nauka, Moscow, p. 240-246

Romankevich, E. A. (1979b). Composition of organic matter. In: Volkov, I. I. (ed.) Chemistry of ocean, Vol. I. Nauka, Moscow, p. 266-277

Rose, A. H. (1968). Chemical microbiology. Butterworths, London.

Shushkina, E. A. (1977). Production of zooplankton. In: Vinogradov, M. E. (ed.) Biology of ocean. Nauka, Moscow, Mp. 233-259

Shushkina, E. A., Vinogradov, M. E., Lebedeva, L. P., Umnov, A. A. (1980). Energetics and structural-functional characteristisc of plankton communities of the Black Sea. In: Vinogradov, M. E. (ed.) Pelagic ecosystems of the Black Sea. Nauka, Moscow, p. 233-242

Sorokin, Yu. I. (1971). On the role of microflora in the productivity of tropical oceanic waters. Int. Revue ges. Hydrobiol. 56: $1-48$

Sorokin, Yu. I. (1973). Data on biological productivity of the western tropical Pacific Ocean. Mar. Biol. 20: 177-196

Sorokin, Yu. I. (1977). The heterotrophic phase of plankton succession in the Japan Sea. Mar. Biol. 41: 107-117 
Sorokin, Yu. I. (1978). Decomposition of organic matter and nutrient regeneration. In: Kinne, $O$. (ed.) Marine ecology, Vol. IV. Wiley, London, p. 501-616

Sorokin, Yu. I. (1979). The red tide in the Peruvian coastal waters. (Russ.). Dokl. Acad. Nauk. SSSR 249: 253-256

Sorokin, Yu. I., Kadota, H. (1972). (Ed.) Techniques for the assessment of microbial production and decomposition in freshwaters. IBP Manual, Oxford, p. 1-112

Sorokin, Yu. I., Wyshkwartzev, D. I. (1974) . Studies of inorganic phosphorus consumption by planktonic communities of tropical waters. (Russ.). Okeanologia (Moscow) 14: 668-692
Thomas, W. H. (1979). Anomalous nutrient:chlorophyll interrelatonships in the offshore estern tropical Pacific Ocean. J. mar. Res. 37: 327-335

Thomas, W. H., Dodson, A. N. (1968). Effects of phosphate concentration on cell division rates and yield of a tropical oceanic diatom. Biol. Bull. mar. biol. Lab. Woods Hole. 134: 199-208

Watt, W. D., Hayes, R. F. (1963). Tracer study of the phosphorus cycle in sea water. Limnol. Oceanogr. 8: 267-285

Yoshida, K. (1967). Circulation in the estern tropical oceans with special references to upwelling and undercurrents in Japan. Geophys. Res. 4: 1-75

This paper was submitted to the editor; it was accepted for printing on July 1st, 1985 